\title{
大阪湾再生水質一斉調査結果から見た大阪湾の水質分布について
}

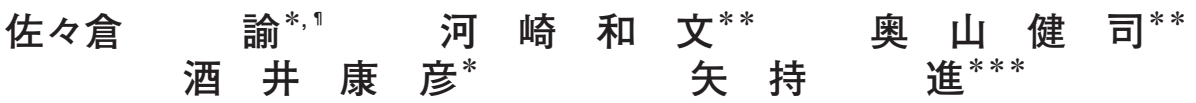

\section{Water Quality in Osaka Bay Based on Simultaneous Water Quality Survey}

\section{Satoshi SASAKURA ${ }^{*, "}$, Kazufumi KAWASAKI**, Kenji OKUYAMA**, Yasuhiko SAKAI* and Susumu YAMOCHI***}

\footnotetext{
* IDEA Consultants, Inc., 1-24-22 Nanko-kita, Suminoe-ku, Osaka 559-8519, Japan

** Kobe Research and Engineering Office for Port and Airport, Kinki Regional Development Bureau, Ministry of Land, Infrastructure, Transport and Tourism, 7-30 Onohama-cho, Chuo-ku, Kobe 651-0082, Japan

*** Department of Urban Engineering, Graduate School of Engineering, Osaka City University, 3-3-138 Sugimoto, Sumiyoshi-ku, Osaka 558-8585, Japan
}

\begin{abstract}
A simultaneous water quality survey in Osaka Bay has been conducted in cooperation with private sectors, universities and governments every summer since 2004. The survey is characterized by almost the same sampling date and sampling depth and by widespread sampling from the shore to the bay mouth. In this report, we describe an overview of the survey and investigate the relationships between climate conditions and the distributions of bottom dissolved oxygen (DO) and surface chemical oxygen demand (COD) as well as the distributions of nitrogen and phosphorus from the shore to the bay mouth. Bottom DO and surface COD, which are indexes of water quality targets in the Action Plan to Revive Osaka Bay, do not reach their target values in the inner bay. These distributions vary according to climate conditions. The dissolved inorganic nitrogen (DIN) and dissolved inorganic phosphorus (DIP) concentrations at the upper layer, which are $0.34 \mathrm{mg} \cdot \mathrm{L}^{-1}$ and $0.032 \mathrm{mg} \cdot \mathrm{L}^{-1}$ in the inner bay, decrease to $0.03 \mathrm{mg} \cdot \mathrm{L}^{-1}$ and $0.008 \mathrm{mg} \cdot \mathrm{L}^{-1}$ in the bay mouth, respectively.
\end{abstract}

Keywords: Simultaneous Water Quality Survey in Osaka Bay; Bottom DO; Surface COD; Nitrogen and Phosphorus; Oligotrophication

1.はじめに

大阪湾では 2004 年から, 企業, 大学, 行政が連携し た大阪湾再生水質一斉調査（以下，一斉調査）が毎年 8 月に継続して実施されている。一斉調査では，沖合の地 点だけでなく，企業，大学等により護岸近くの地点にお いても，ほぼ同日に，統一された水深において水質測定 が実施されている。

大阪湾の湾奥部では，陸域からの流入負荷の集中や閉 鎖的な地形の影響により，有機污濁や底層の貧酸素化な どの問題が生じている。一方，窒素・リンの総量削減に より，陸域からの流入負荷量は減少し，湾口部では貧栄 養化していることも指摘されている ${ }^{1,2)}$ 。

本報告では, 一斉調査の概要について述べるとともに, 8 年間にわたって継続的に実施されてきた一斉調査の結 果を用いて，夏季における大阪湾の底層 DO, 表層 COD
の分布と気象条件との関係, 湾奥部〜湾口部における窒 素・リンの分布について述べる。

\section{2. 大阪湾再生水質一斉調査について}

これまで大阪湾においては，国土交通省，海上保安庁， 地方公共団体の環境部局，水産部局等の様々な機関によ り水質調查が実施されてきた。これらの水質調査は, 海 洋環境改善事業の効果把握, 公共用水域における環境基 準の達成状況の把握や漁場環境の監視等, 様々な目的の もとに実施されており，調査日や測定層は各機関により 独自に設定されている。このため, 大阪湾においては数 多くの調査地点が配置されているものの, 調査日や測定 層が異なるために, 空間的な比較をするための水質デー 夕を得ることが難しかった。

そこで, 大阪湾再生行動計画が, 大阪湾再生推進会議 により 2004 年に策定されたことを契機として, 土木学

* いであ株式会社大阪支社環境調查・技術部％ 559-8519 大阪市住之江区南港北 1-24-22

** 国土交通省近畿地方整備局神戸港湾空港技術調查事務所 $\overline{\mathrm{T}}$ 651-0082 神戸市中央区小野浜町 7-30

*** 大阪市立大学大学院工学研究科都市系専攻 $=$ 558-8585 大阪市住吉区杉本 3-3-138

凤 連絡先 : ssatoshi@ideacon.co.jp 
会関西支部共同研究グループ「都市型塩性湿地研究会」 は，地方公共団体等に働きかけ，2004 年 8 月に第 1 回 目の一斉調查を実施した ${ }^{3)}$ 。その後, 国土交通省近畿地 方整備局が事務局となり，各機関の協力を得て毎年 8 月 に継続して実施されている。一斉調查が始まった 2004 年には, 総調査地点数 410 点, 総参加機関数 30 機関で あったが，その後の事務局による継続的な働きかけや調 査結果の公表により, 調査地点数, 参加機関数ともに増 加し, 2011 年にはそれぞれ 495 地点, 44 機関となった（表 1)。2011 年の調查地点は図 1 に示すとおりであり，陸 域を含めた多くの地点で測定が実施されている。この取 り組みはその後, 東京湾, 伊勢湾, 広島湾へと展開された。

測定日は，水質が悪化しやすい 8 月のうち，多くの機 関が定期調查を実施する上旬の小潮期を基本として設定 している。なお，本報告では，設定した測定日以外に実 施された測定デー夕も含めて整理を行っている。

測定項目は，大阪湾再生行動計画において目標水質の 指標として設定されている底層 DO, 表層 COD が必須 項目として定められており，2009年からは，大阪湾再 生行動計画のアウトカム指標として設定された透明度が 必須項目として追加された。この他, 測定機関により水 温, 塩分, 窒素, リンなどが測定されている。なお, 底
層 DO と透明度は, 現在環境省において環境基準值の設 定に向けた検討が進められており, 現状把握が急がれて いる項目である。

測定層は, 表層は海面下 $0 \sim 2 \mathrm{~m}$ 層の平均值（海面下 $1 \mathrm{~m}$ 又は海面下 $0.5 \mathrm{~m}$ と $2 \mathrm{~m}$ の平均值), 底層は海底面 上 $1 \mathrm{~m}$ を原則としている。なお, 本報告では, 原則とし た水深以外での測定デー夕も含めて整理を行っている。

測定方法は, 参加機関によって異なり, 底層 DO は採 水分析または機器測定, 表層 COD は採水分析（酸性法, アルカリ性法）とパックテスト（2011 年の尼崎港周辺 の 4 地点のみ), 窒素・リンは採水分析により測定が行 われている。なお, 表層 COD は酸性法とアルカリ性法 により值が大きく異なるため, 本報告では, アルカリ性 法（大阪湾全域の 20 地点）のデータは整理対象外とし ている。

毎年 6 月頃に, 参加機関を対象とした一斉調査に関す る連絡会が開催され, 測定日や測定方法などの実施計画 について調整が行われている。

\section{3. 水質分布と気象条件との関連性}

一斉調查は, 毎年 8 月上旬の小潮期に実施されており, 降水量や風速などの気象条件は年によって異なる。この

表 1 調査地点数と参加機関数

\begin{tabular}{ccccccccc}
\hline 調査年 & 2004 & 2005 & 2006 & 2007 & 2008 & 2009 & 2010 & 2011 \\
\hline 調查日 & $8 / 2$ & $8 / 2$ & $8 / 2$ & $8 / 7$ & $8 / 5$ & $8 / 5$ & $8 / 3$ & $8 / 5$ \\
海域 地点 & 160 & 206 & 217 & 208 & 194 & 214 & 204 & 199 \\
異なる調査日に実施 & $(57)$ & $(49)$ & $(51)$ & $(35)$ & $(84)$ & $(95)$ & $(58)$ & $(44)$ \\
I 湾奥部海域 & $(58)$ & $(81)$ & $(94)$ & $(84)$ & $(85)$ & $(89)$ & $(86)$ & $(81)$ \\
II 湾東部水深20m以浅海域 & $(78)$ & $(103)$ & $(101)$ & $(102)$ & $(87)$ & $(101)$ & $(95)$ & $(95)$ \\
III湾口部水深20m以深海域 & $(24)$ & $(22)$ & $(22)$ & $(22)$ & $(22)$ & $(24)$ & $(23)$ & $(23)$ \\
機関 & 12 & 20 & 22 & 24 & 28 & 31 & 28 & 28 \\
異なる調査日に実施※2 & $(6)$ & $(4)$ & $(6)$ & $(3)$ & $(11)$ & $(9)$ & $(7)$ & $(7)$ \\
\hline 陸域 地点 & 250 & 242 & 266 & 253 & 246 & 262 & 266 & 296 \\
異なる調查日に実施 & $(250)$ & $(93)$ & $(136)$ & $(129)$ & $(87)$ & $(208)$ & $(118)$ & $(280)$ \\
琵琶湖を除く & $(250)$ & $(242)$ & $(229)$ & $(216)$ & $(209)$ & $(225)$ & $(229)$ & $(259)$ \\
機関 & 18 & 17 & 17 & 17 & 16 & 16 & 16 & 16 \\
異なる調査日に実施※2 & $(18)$ & $(5)$ & $(7)$ & $(7)$ & $(5)$ & $(16)$ & $(6)$ & $(16)$ \\
\hline ※1 調查日は主要な調查日を示し, 一部の調查機開は異なる調查日に実施している & & &
\end{tabular}

$※ 2$ 一部地点の夕異なる調査日に実施した機関を含む

注）括弧内は内数

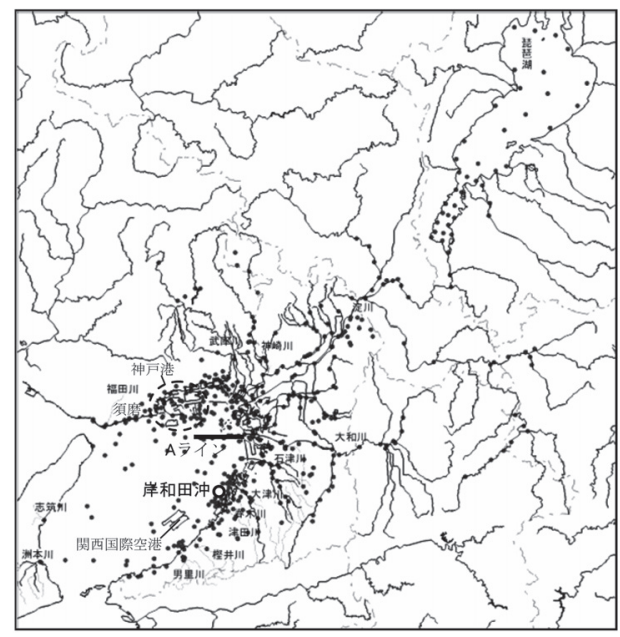

図 1 大阪湾再生水質一斉調査地点 (2011年)

A ランは国交省近畿地方整備局測定地点, 岸和田沖 は国交省近畿地方整備局による定点観測地点
表2 気象の状況と気象区分

\begin{tabular}{|c|c|c|}
\hline 年 & 気象区分 & 気象の状況 \\
\hline 2004 & 強風後 & $\begin{array}{l}\text { 調査実施 2 3 日前に台風が通過し, 北東〜東北東か } \\
\text { ら最大風速 } 12 \mathrm{~m} \cdot \mathrm{s}^{-1} \text { を超える強い風が連吹した。 }\end{array}$ \\
\hline 2005 & 平常時 & $\begin{array}{l}\text { 大規模な降雨や台風の通過等はなく, 比較的晴天が継 } \\
\text { 続した。 }\end{array}$ \\
\hline 2006 & 出水後 & $\begin{array}{l}\text { 調査実施 8〜 } 17 \text { 日前に合計 } 270 \mathrm{~mm} \text { を超える降雨が観 } \\
\text { 測された。 }\end{array}$ \\
\hline 2007 & $\begin{array}{l}\text { 強風後 } \\
\text { （規模小） }\end{array}$ & $\begin{array}{l}\text { 調査実施 } 4 \text { ～５ 日前に台風が接近し，東〜南から最大 } \\
\text { 風速 } 8 \mathrm{~m} \cdot \mathrm{s}^{-1} \text { を超える風が観測された。調查実施 } 1 \text { 週 } \\
\text { 間前から前日において降水は観測されなかった。 }\end{array}$ \\
\hline 2008 & 平常時 & $\begin{array}{l}\text { 大規模な降雨や台風の通過等はなく, 比較的晴天が継 } \\
\text { 続した。 }\end{array}$ \\
\hline 2009 & $\begin{array}{l}\text { 出水後 } \\
\text { (規模小) }\end{array}$ & $\begin{array}{l}\text { 調査実施 } 3 \text { 日前に } 10 \mathrm{~mm} \text { 程度の降雨が観測された。大 } \\
\text { 規模な降雨や台風の通過等はなかった。 }\end{array}$ \\
\hline 2010 & $\begin{array}{l}\text { 出水後 } \\
\text { (規模小) }\end{array}$ & $\begin{array}{l}\text { 調查実施 } 5 \text { 日前に } 30 \mathrm{~mm} \text { 程度の降雨が観測された。大 } \\
\text { 規模な降雨や台風の通過等はなかった。 }\end{array}$ \\
\hline 2011 & $\begin{array}{l}\text { 強風後 } \\
\text { （規模小） }\end{array}$ & $\begin{array}{l}\text { 調査前日から当日に台風が接近し，東〜北東から最大 } \\
\text { 風速 } 7 \mathrm{~m} \cdot \mathrm{s}^{-1} \text { を越える風が観測された。調査実施 } 1 \text { 週 } \\
\text { 間前から前日までの降水量は } 32.5 \mathrm{~mm} ゙ \text { あ゙あた。 }\end{array}$ \\
\hline
\end{tabular}


ことに注目し，大阪湾再生行動計画において目標水質の 指標として設定されている底層 DO, 表層 COD について, 毎年の水質分布と気象条件との関連性について調べた。

\section{1 調査実施時の気象状況}

各調査年における気象の状況を整理し, 平常時, 出水 後, 強風後の 3 パターンに区分した。気象データ（降水 量および風速) は大阪管区気象台の観測結果に基づいた。 結果は表 2 に示すとおりであり, 2004 年は強風後, 2007 年, 2011 年は, 2004 年と比較して規模の小さい強風後, 2006 年は出水後, 2009 年, 2010 年は, 2006 年と比較し て規模の小さい出水後, その他の年は平常時に分類した。

\section{2 水質分布}

各調査年における表層塩分の水平分布を図 2 に示す。 2004 年の強風後には, 全域で高塩分となった。2006 年 の出水後には, 塩分 26 以下の低塩分水が大阪湾の北側 を中心に拡がり, 須磨付近にまで拡散していることが確 認された。2010 年の規模の小さい出水後には, 低塩分 水は大阪湾の東側を中心に分布しており, 関西国際空港 付近にまで及んでいた。

淀川の河川水は, 出水時には北岸に沿って西に向か い, 平常時には東岸に沿って南下すると言われてい る ${ }^{4)}$ 。2006 年と 2010 年の塩分の分布状況が異なる要因 としては, 淀川の河川流量の違いや出水後の経過時間の 違いによるものと考えられる。

各調査年における底層 DO の水平分布を図 3 に示す。 大阪湾再生行動計画では, 底層 DO の目標值を $5 \mathrm{mg} \cdot \mathrm{L}^{-1}$ 以上（当面は $3 \mathrm{mg} \cdot \mathrm{L}^{-1}$ 以上）と設定している。いずれ の年においても, 湾奥部の岸近くにおいて, 当面の目 標值である $3 \mathrm{mg} \cdot \mathrm{L}^{-1}$ を下回る水域が見られた。出水後 の 2006 年には神戸港を中心に, 広い範囲で $3 \mathrm{mg} \cdot \mathrm{L}^{-1}$ 未 満となっていた。2004 年の強風後には湾奥部の岸近く を除いて, 大阪湾全域で高い值となっていた。2011年 には岸側では底層 DO が比較的高く, 沖側の地点で底層 DOの低い水域が見られた。

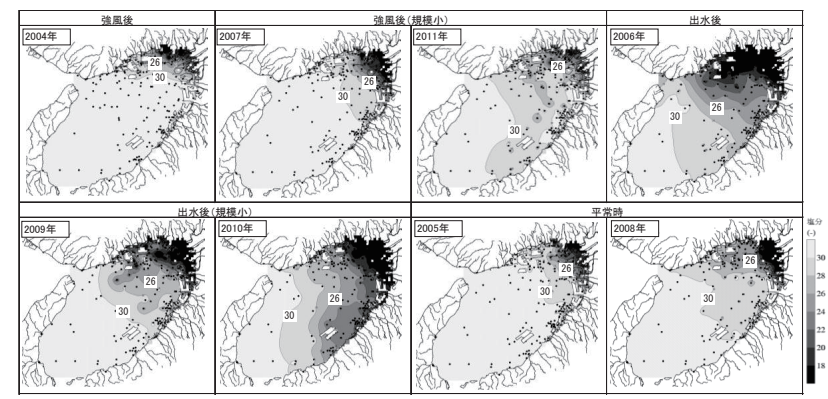

図2 表層塩分の水平分布

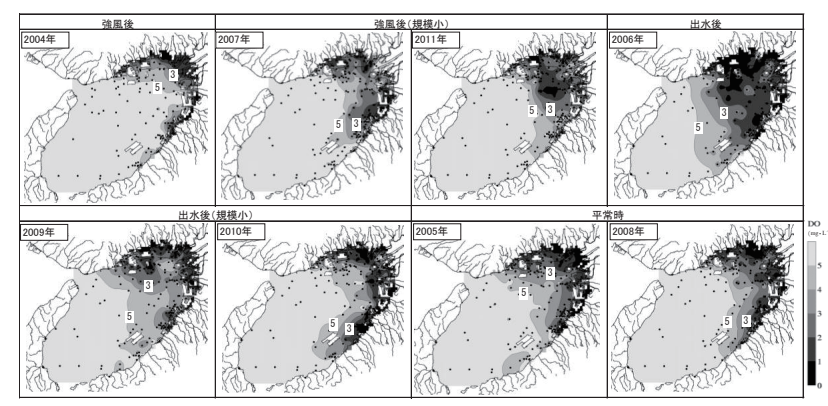

図3 底層 $\mathrm{DO}$ の水平分布
各調査年における表層 COD の水平分布を図 4 に示す。 大阪湾再生行動計画では, 表層 COD の目標值を, 異な る活動目的に適した水質レベルとして,「散策, 展望： $5 \mathrm{mg} \cdot \mathrm{L}^{-1}$ 以下」, 「潮干狩り $: 3 \mathrm{mg} \cdot \mathrm{L}^{-1}$ 以下」, 「海水浴 :

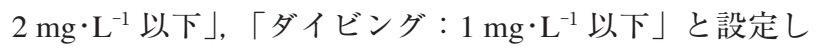
ている。いずれの年においても, 湾奥部を中心に, 散策, 展望に適した水質レベルの $5 \mathrm{mg} \cdot \mathrm{L}^{-1}$ を上回る水域が見 られた。2006 年の出水後には神戸港を中心に, 広い範 囲で $5 \mathrm{mg} \cdot \mathrm{L}^{-1}$ を上回る值となっていた。 2011 年の強風 後には湾奥部の岸近くを除いて, 大阪湾全域で低い值と なっていた。

底層 DO と表層 COD の濃度別分布面積の割合を気象 区分別に整理して図 5 に示す。底層 DO $03 \mathrm{mg} \cdot \mathrm{L}^{-1}$ 未 満の分布面積は, 強風後および強風後 (規模小) が最も 小さく, 出水後が最も大きく, 出水後 (規模小) および 平常時はそれらの中間程度となっていた。表層 CODの $5 \mathrm{mg} \cdot \mathrm{L}^{-1}$ 以上の面積は, 底層 $\mathrm{DO}$ と同様に強風後および 強風後（規模小） が最も小さく, 出水後が最も大きく, 平常時は出水後と同程度もしくはやや小さい程度, 出水 後（規模小）は中程度となっていた。

底層 DO の分布面積の違いについては, 出水時には, 表層の低塩分化による成層の発達や, 陸域からの有機物 の流入により貧酸素化が助長され, 強風後には, 鉛直混 合により底層の貧酸素化が解消されるためと考えられ る。また, 大阪湾東部海域の貧酸素水塊は, 大阪湾の西 部海水が東部水域に進入する深度の違い等に影響される ことが報告されており，これによる影響も考えられる ${ }^{5)}$

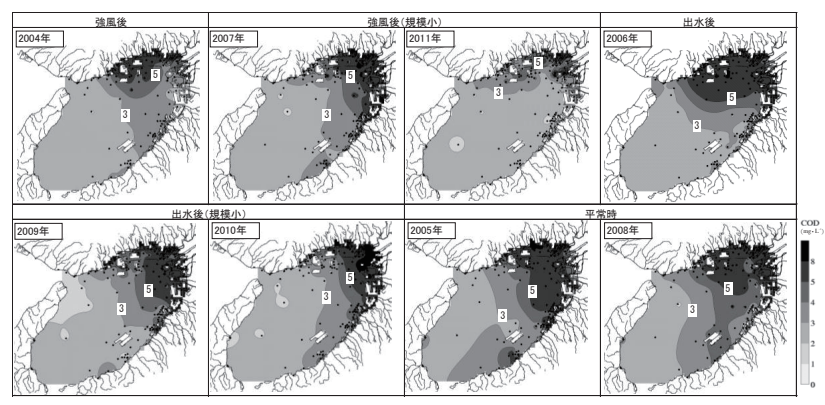

図4 表層 $\mathrm{COD}$ の水平分布

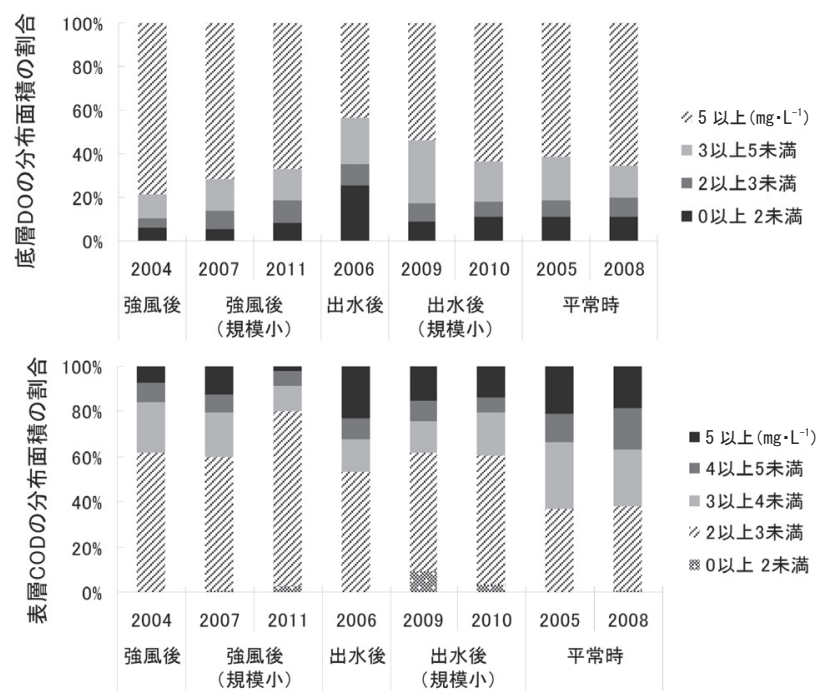

図5 底層DO (上) と表層 COD (下) の濃度別分布面積の割合 
表層 COD の分布面積の違いについては, 出水時には, 陸域からの有機物や栄養塩の流入によって COD が高く なり, 台風通過等の強風後には, 底層の $\mathrm{COD}$ が低い水 と鉛直混合し，希釈されることによると考えられる。平 常時は, 内部生産により COD が増加し, 規模の小さい 出水時にはエスチュアリー循環により海水交換が促進さ れ, 平常時よりも COD が低下することが一つの要因と して推測される。

次に，水温の連続観測結果と鉛直断面分布から，規模 の小さい出水後の 2010 年と強風後の 2011 年における成 層状況と水塊構造について示す。

国土交通省近畿地方整備局により，2010 年 4 月から 大阪湾の 13 定点において水温, 塩分, DO, クロロフィ ル a や光量子などの水質の連続観測が行われている。こ のうち, 2010 年と 2011 年の岸和田沖の定点（図 1) に おける一斉調查実施 14 日前からの水温の測定結果を図 6 に示す。 2010 年には, 調査当日の表層（海面下 $0.5 \mathrm{~m}$ ) と底層（海面下 $13 \mathrm{~m}$ ）の水温差は $8^{\circ} \mathrm{C}$ 程度であったのに 対し, 2011 年では $2^{\circ} \mathrm{C}$ 程度と小さくなっていた。

国土交通省近畿地方整備局が一斉調査当日に測定した 大阪沖から神戸沖に至る測線（A ライン，図 1) におけ る水温の鉛直断面分布を図 7 に示す。連続観測結果と 同様に, 2011 年は 2010 年と比較して成層が弱くなって いることがわかる。また, 2011 年には神戸沖の底層に, 周囲よりもわずかに水温の低い水塊が見られた。

2011 年に成層が弱くなっていた原因としては, 調査 実施 8 日前に観測された前線の影響による風や，調查当 日の台風の接近による風の影響に加え, 2010 年と比較
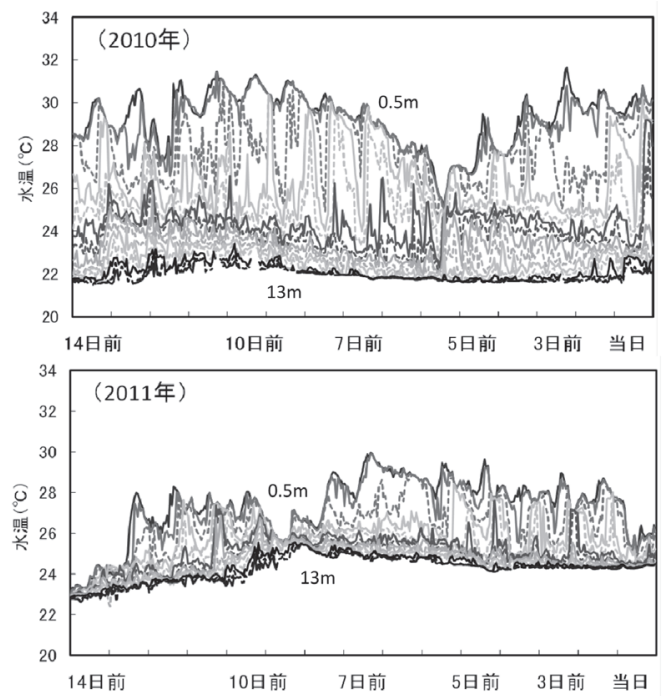

測定水深 $(m)$

図 6 岸和田沖における水温の経時変化 （上：2010年,下：2011年)

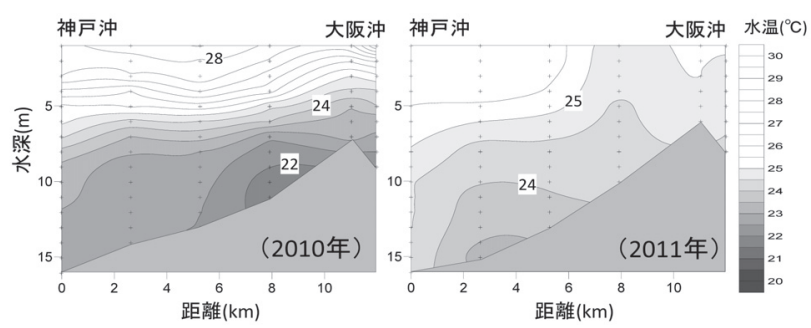

図 7 A ラインにおける水温鉛直断面分布 （左：2010年, 右：2011年)
して 2011 年には気温が低く成層が発達しにくかったこ とが考えられる。

図 3 で示した通り, 2011 年には大阪側の岸側で底層 $\mathrm{DO}$ が高く, 沖側の海域で底層 DO が低くなっている水 域が見られた。この要因として, 岸側では強風の影響に より成層が崩壊しているものの, 沖側の底層では低水温 の水塊が維持されて, 低 DO となっていたことが考えら れる。

\section{4. 形態別の窒素・リンの分布特性}

瀬戸内海をはじめとする日本の多くの内湾で，栄養塩 が不足する貧栄養化が報告されている ${ }^{1,2)}$ 。大阪湾も例 外では無いものの, 栄養塩類の空間的に詳細なデー夕は そしく，その実態はよくわかっていない。そこで，護岸 近くから沖合までの多地点で測定されている一斉調査の 特徵を活かして, 大阪湾における形態別の窒素・リンの 分布特性を整理した。

解析にあたっては，大阪湾を，主に防波堤等に囲まれ た湾奥部海域 ( I ), 湾東部の水深 $20 \mathrm{~m}$ 以浅の海域 (II ), 湾口部の水深 $20 \mathrm{~m}$ 以深の海域（III）に区分し，8 年間 の全デー夕を海域ごとに平均した（図 8)。河川におい ては, 琵琶湖を除く各河川で測定された 8 年間のデータ を, 全地点で平均した。

河川から湾口部（III 海域）に至る形態別の窒素・リ ン濃度を図 9, 図 10 に示し, T-N, T-P に対する有機態 窒素, 有機態リンの割合を図 11 に示す。ここで, 有機 態窒素（Org.N）は T-N - DIN（ $\left.\mathrm{NO}_{2}-\mathrm{N}+\mathrm{NO}_{3}-\mathrm{N}+\mathrm{NH}_{4}-\mathrm{N}\right)$, 有機態リン（Org.P）は T-P - DIP ( $\left.\mathrm{PO}_{4}-\mathrm{P}\right)$ とした。なお, 厳密には懸濁態の無機窒素やリンも含まれるものと考え られるが, 海域においてはわずかな量と考えられるため,

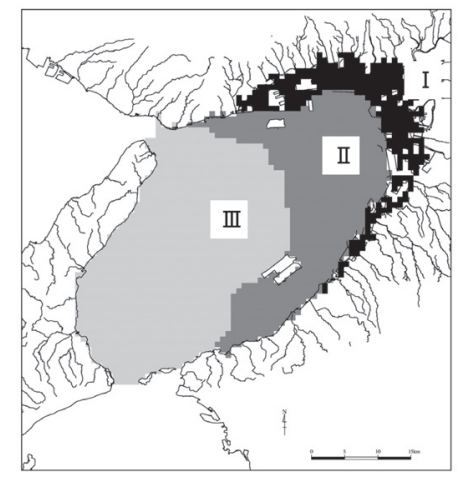

図8 海域区分

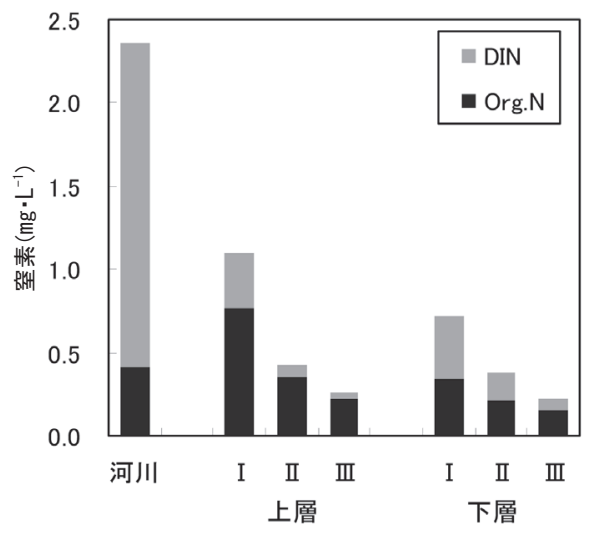

図9 河川・海域の無機態・有機態窒素濃度 


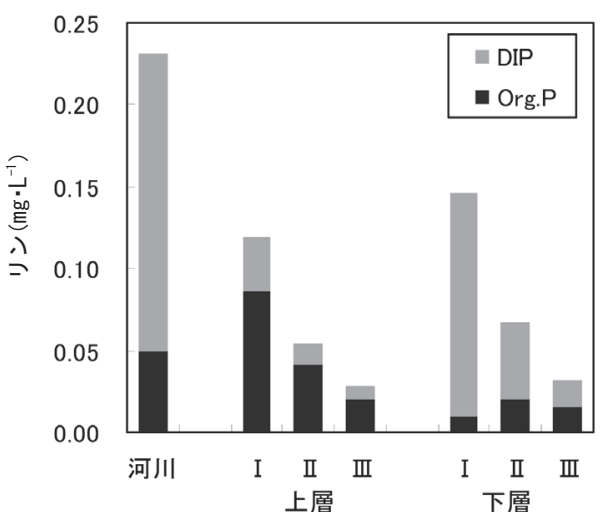

図 10 河川・海域の無機態・有機態リン濃度

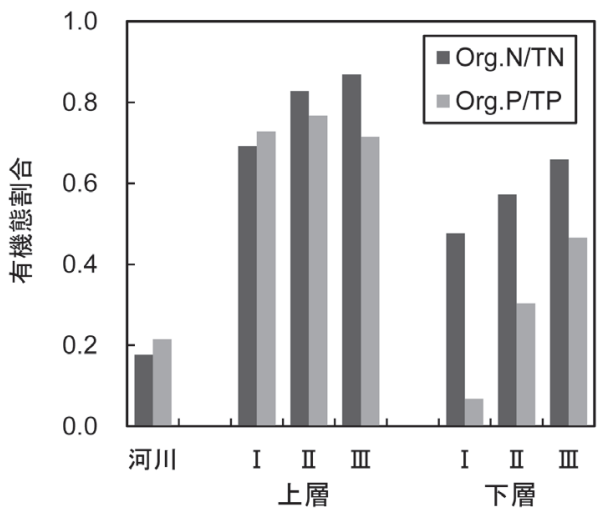

図 11 河川・海域の窒素・リンの有機態割合

便宜上有機態と表記した。

T-N， T-P の濃度は, 河川から湾口部に向かうにつれ て低くなっていた。海域の上層と下層の濃度を比較する と, T-N では I 海域においては上層の方が高く， II , III 海域においては同程度の值となっていた。T-Pでは I, II ， III 海域ともに下層の方が高く，その傾向は I 海域で 顕著に見られた。

形態別にみると，河川では窒素，リンともに 8 割程度 が無機態となっていた。海域に入ると，DIN，DIP の濃 度が減少し， I 海域の上層では 7 割程度が有機態となっ ていた。その後, 湾口部の III 海域に向かうにつれて上層, 下層ともに有機態の割合が増加する傾向が見られ， III 海 域の上層の窒素は 9 割弱が有機態であった。DIN, DIP の濃度は, 上層よりも下層の方が高く, リンで顕著で あった。また, I 海域の下層では DIP 濃度が極めて高く, 9 割以上が無機態となっていた。山本 ${ }^{6)}$ は, 珪藻類の Skeletonema costatum の DIN, DIP の半飽和值について, それぞれ $5.9 \mu \mathrm{M}\left(0.083 \mathrm{mg} \cdot \mathrm{L}^{-1}\right), 0.68 \mu \mathrm{M}\left(0.021 \mathrm{mg} \cdot \mathrm{L}^{-1}\right)$ としている。Skeletonema costatum は, 大阪湾で出現す る代表的な植物プランクトンである。I 海域の上層での DIN，DIP 濃度は，それぞれ $0.34 \mathrm{mg} \cdot \mathrm{L}^{-1}, 0.032 \mathrm{mg} \cdot \mathrm{L}^{-1}$ と Skeletonema costatum の半飽和值を大きく上回ってお り，植物プランクトンが十分に生産できる程度に存在し ていると考えられるのに対し， III海域の上層では，それ ぞれ $0.03 \mathrm{mg} \cdot \mathrm{L}^{-1}, 0.008 \mathrm{mg} \cdot \mathrm{L}^{-1}$ と Skeletonema costatum の半飽和值の半分以下にまで低下していた。

上層の DIN/DIP 比（モル比）は，河川および I 海域 では，それぞれ 23.7，23.3とレッドフィールド比 ${ }^{7)}(16)$ よりも高く， II， III海域ではそれぞれ 13.1，9.3 と，レッ ドフィールド比よりも低かった。
河川から流入した無機態の窒素, リンは, 海域で植物 プランクトンに取り込まれ有機態に変化する。湾奥部の I 海域でそのほとんどが植物プランクトンに取り込ま れ, 湾口部の上層では DIN, DIP 濃度が低くなっている ものと考えられる。II 海域, III 海域での DIN/DIP 比は レッドフィールド比よりも低いことから, 夏季の大阪湾 においては植物プランクトンの増殖に関して窒素制限に なり易いと推察される。

下層のリン, 特に I 海域の DIP 濃度が高い理由につい ては, 貧酸素化に伴う底泥からのリンの溶出 ${ }^{8)}$ や, 河川 水中のリンが海水に接触すると䋰濁態となって沈降・蓄 積し ${ }^{1)}$ ，バクテリアにより無機化されることが考えられ る。大阪湾における DIN/DIP 比は, 湾奥部よりも湾口部 で低くなること ${ }^{9)}$, 冬季よりも夏季で低くなること ${ }^{10)}$, が報告されている。林・柳 ${ }^{10)}$ は, DIN/DIP 比が夏季に低 くなることについて, DIN の季節変化は小さい一方で, 夏季には貧酸素化による底泥からの溶出のため DIP が高 くなるためと考察している。また, 筧・藤原 ${ }^{11}$ は, リン の溶出に加え, 脱窒が盛んになり, DIN/DIP 比が低下し た下層水が上層に供給されるためと考察している。湾口 部で DIN/DIP 比が低くなる理由については, DIP につい ては下層から上層に供給されるが, DIN は下層からの供 給が少なく, 湾奥部の I 海域において多くが植物プラン クトンにより消費され, 低濃度になるためと考えられる。

また，矢持（1993）の測定結果 ${ }^{9)}$ を用いて1979〜 1991 年夏季の大阪湾表層における DIN/DIP 比を整理し た結果, 湾奥域平均で $2.4 \sim 215.9$ (平均 75.0), 湾全域 20 定点平均で $4.8 \sim 83.8$ (平均 25.2) となり, 近年はこ れよりも明らかに值が低くなっている。これには, 下水 処理場における窒素除去技術の向上とともに, 海域にお ける難分解性有機態窒素の増加 ${ }^{12,13)}$ が関与している可能 性がある。

\section{5. おわりに}

一斉調査の継続により, 異なる気象条件において, 空 間的に比較可能な水質分布が得られた。

底層 DO, 表層 COD は, 湾奥部の海域で目標值を達 成しておらず, 未達成海域の分布や面積は気象条件に より異なっていた。大阪湾では 2010 年 4 月より, 大阪 湾水質定点自動観測システムが構築され, 大阪湾内の 13 定点における水温, 塩分, DO, クロロフィル a や 光量子などのデータがリアルタイムで公開されている (http://222.158.245.253/obweb/index.aspx)。今後, これら のデータを有効に活用し, 大阪湾の污濁機構を解明する ことが期待される。

窒素・リンについては, 湾奥部の I 海域上層での DIN，DIP 濃度は，それぞれ $0.34 \mathrm{mg} \cdot \mathrm{L}^{-1}, 0.032 \mathrm{mg} \cdot \mathrm{L}^{-1}$ と植物プランクトンが十分に生産できる程度に存在して いるのに対し， III海域上層では，それぞれ $0.03 \mathrm{mg} \cdot \mathrm{L}^{-1}$, $0.008 \mathrm{mg} \cdot \mathrm{L}^{-1}$ にまで低下していた。湾奥部では富栄養で あるのに対し，湾口部では貧栄養状態となっている。ま た，II およびIII 海域の上層では窒素の 8 割以上が有機態 によって占められ, 植物プランクトンや海藻類などの生 産に及ぼす影響が懸念される。今後は，大阪湾において も, 適切な水環境のモニタリングと栄養塩管理を行って いくことが必要である。 


\section{謝 辞}

本報告は, 大阪湾再生水質一斉調査に参加している企 業，大学，地方および国の行政機関ならびに試験研究機 関が取得したデータをとりまとめたものです。その継続 的な活動に対して敬意を表すとともに，ご支援・ご協力 に深く感謝いたします。また，調査結果の整理に協力頂 いた, いであ株式会社の宮崎太一郎氏, 豊島沙織氏に厚 くお礼申し上げます。

(原稿受付 2012 年 5 月 23 日)
(原稿受理 2012 年 9 月 14 日)

参 考 文 献

1 ) 藤原建紀, 駒井幸雄 (2009) 沿岸海域の栄養塩動態, 海洋と生 物, 31, 134-140.

2 ) 藤原建紀 (2011) 瀬戸内海の貧栄盖化, 水環境学会誌, 34 (A), 34-38.

3 ) 矢持進 (2009) 大阪湾水質一斉調查の経緯と「大阪湾環境再生 推進プラットフォーム」について, 関西自然保護機構会誌, 31 (2), 107-109.

4 ）金種仁，中辻啓二,村岡浩爾（1996）大阪湾の底質特性と淀川 洪水時の挙動特性との関連性, 海岸工学論文集, 43, 336-340.

5 ) 藤原建紀, 岸本綾夫, 中嶋昌紀 (2004) 大阪湾の貧酸素水塊の
短期的抢よび長期的変動, 海岸工学論文集, 51, 931-935.

6 ）山本民次 (1998) 沿岸環境圈の科学, 植物プランクトン, 「沿岸 の環境圈」(平野敏行監修), pp.144-174, フジ・テクノシステム, 東京.

7 ) Redfield, A. C., Ketchum, B. H. and Richards, F. A. (1963) The influence of organisms on the composition of seawater, in "The Sea Vol. 2" (Ed. Hill, M. N.), pp.26-77, John Wiley, New York.

8 ）城久 (1986) 大阪湾に抢ける富栄養化の構造と富栄養化が漁 業生産に及ぼす影響について, 大阪府水産試験場研究報告, 7, 1-174.

9 ) 矢持進 (1993) 水域別の水産生物に及ぼす N : P 比の影響：大 阪湾,「水域の窒素：リン比と水産生物」(吉田陽一編), pp.84-95, 恒星社厚生閣, 東京.

10) 林美鶴, 柳哲雄 (2000) 伊予灘南部 · 大阪湾に打ける DIN · DIP濃度と N/P比の変遷, 海の研究, 9, 133-142.

11）筧茂穂, 藤原建紀 (2009) 数值モデルによる栄養塩動態の解明, 海洋と生物, 31, 123-128.

12）仲川直子, 金澤良昭, 梅本諭, 上村育代 (2008) 大阪湾海水中 難分解性有機物の特性について, 兵庫県立健康環境科学研究セ ンター紀要, 5, 89-94.

13）中嶋昌紀, 松本弘史, 矢持進 (2012) 大阪湾扔よび淀川・大和 川における難分解性有機窒素の動態について, 土木学会論文集 B2 (海岸工学), 68, I_1036-I_1040.

\section{[論 文 要 旨]}

大阪湾では, 2004 年から企業, 大学, 行政が連携した大阪湾再生水質一斉調査（以下, 一斉調查）が毎 年 8 月に継続して実施されている。一斉調査では, 沖合の地点だけでなく, 企業, 大学等により護岸近くの 地点においても，ほぼ同日に，統一された測定水深において水質測定が実施されている。本報告では，一斉 調査の概要について述べるとともに, 夏季の底層 DO, 表層 COD の分布と気象条件との関係, 湾奥〜湾口 部における窒素・リンの分布について示した。底層 DO, 表層 COD は, 湾奥部の海域で目標値を達成して おらず，未達成海域の分布や面積は気象条件により異なっていた。DIN, DIP 濃度は, 湾奥部の上層では, それぞれ $0.34 \mathrm{mg} \cdot \mathrm{L}^{-1}, \quad 0.032 \mathrm{mg} \cdot \mathrm{L}^{-1}$ と植物プランクトンが十分に生産できる程度に存在しているのに対し, 湾口部の上層では，それぞれ $0.03 \mathrm{mg} \cdot \mathrm{L}^{-1}, 0.008 \mathrm{mg} \cdot \mathrm{L}^{-1}$ にまで低下していた。

\section{キーワード：大阪湾再生水質一斉調査；底層 DO；表層 COD；窒素・リン；貧栄養化}

